\title{
Business Planning of Ibnu Sina Magelang Hospital
}

\author{
Mochamad Yusuf Kurniawan ${ }^{\mathrm{a} *}$ \\ a toyie_fuchi@yahoo.com \\ ${ }^{a} J l$. Merpati No. 18 Genteng, Kota Banyuwangi and 68465,Indonesia
}

\begin{abstract}
RSI Ibnu Sina Magelang is a private health service, which has not been running a health service business for 6 years due to bankruptcy. Because the hospital has been out of operation for more than 3 years, it is the obligation of each hospital to renew its licensing and accreditation according to Article 40 of the Hospital Law number 44/2009. And based on the mandate of Law Number 44 of 2009 concerning Hospitals and Regulation of the Minister of Health of the Republic of Indonesia Number 147 / MENKES / PER / I / 2010 concerning Hospital Licensing, it is necessary to conduct a feasibility study first by analyzing external and internal factors.

In this study, economic analysis was carried out using the Average Rate Of Return (ARR), Payback Period (PP), Benefit Cost Ratio (B / C Ratio), Net Present Value (NPV) and Internal Rate of Return (IRR).

From the analysis of external and internal factors, RSI Ibnu Sina Magelang has fulfilled the development and development of health service facilities. The results of economic analysis with an investment value of hospital development of Rp. 133,200,000,000, - and a project life of 30 years resulting in an ARR of 66.75\%, a payback period of 5 years and 4 months, a positive NPV of Rp. 19,700,152,955, -, Net B / C of 1.205 and IRR of $13.82 \%$. From the results of this analysis, it can be concluded that the investment in the development and development of health facilities at RSI Ibnu Sina Magelang is feasible.
\end{abstract}

Keyword: Hospital Business Plan, External and internal environmental analysis, porter five's model, financial calculations and analysis.

\section{Preliminary}

Initially on August 19, 1992, a social organization engaged in the health sector was established under the name "ngudi mulyo foundation" and formed the Ibnu Sina Islamic Hospital. Since the establishment of the Ibnu Sina Magelang Islamic Hospital up to now there have been 4 (four) changes to the chairman of the board, and the hospital's operational permit has been extended 4 (four) times. Ibnu Sina Islamic Hospital is located on Jl. Magelang-Purworejo Km.4 Banjarnegoro Mertoyudan Number 129 Magelang and the area of land owned by the hospital is $5,370 \mathrm{~m} 2$.

In 2013 the Ibnu Sina Magelang Islamic Hospital went bankrupt, so that in that year the Ibnu Sina Magelang Islamic Hospital was closed. There were several factors that caused the bankruptcy of the Ibnu Sina Magelang Islamic Hospital, the existence of fraud in the management system, not being ready for development, not having investors to support financing, inadequate equipment so that the Ibn Sina Hospital could not compete. In 2019 the Ibnu Sina Magelang Islamic Hospital through a meeting of the 
Ngudi Mulyo foundation, the management agreed to develop and re-run the business of the Ibnu Sina Islamic Hospital.

The objectives of this research are as follows: In order to be made as a reference for building and developing the Islamic Hospital Ibnu Sina Magelang; improve the hospital management system; market analysis; internal and external environmental analysis; have a description of the strengths, weaknesses, opportunities and threats that are developing; 4P marketing strategy (product, place, price, promotion); human resource management, financial planning and capital.

\section{Literature Review}

2.1. In order to have an overview of the market potential for the Islamic hospital services of Ibn Sina Magelang.

There are 5 main components used to develop a strategy for the Islamic Hospital Ibnu Sina Magelang:

- $\quad$ Rivalry Among Competing Firms

- Potential Entry of New Competitors

- Potential Development of Substitute Products

- Bargaining Power of Supplier

- Bargaining Power of Consumers

2.2. External and internal environmental analysis that will be carried out to support the development of the Islamic Hospital Ibnu Sina Magelang as follows:

- External environment analysis (PEST analysis)
a) Politics, Economy, Social and Technology
b) Opportunities
c) Threats

- Internal Environmental Analysis
a) Strength
b) Weaknesses

2.3. In order for the Ibn Sina Hospital to develop a business in the health sector, financial calculations and analysis are needed, including:

- Economic Analysis

- $\quad$ Capital Structure

- $\quad$ Projected Income Statement

- Balance Sheet Projections

- Cash Flow Projection

- Analysis of Break Even (Break Even Point)

- Capital Budgeting Analysis (Capital Budgeting) 


\section{Research Methods}

This research was conducted using three stages of research, including:

- This type of research is descriptive research. Descriptive research is a research method with the main objective of making a picture or description of a situation objectively to solve or answer the problems that are being faced in the current situation.

- The study used five competitive forces analysis, SWOT analysis, external and internal environmental analysis. The results of the analysis will be validated with a type D hospital in Magelang Regency.

- This research uses financial analysis, economic analysis, capital structure, projection of profit and loss statements, balance sheet projections, cash flow projections, break even point analysis and capital budgeting analysis.

3.1. Descriptive research

The preliminary study was carried out by reviewing documents, field observations, and unstructured interviews conducted in the community sector around the Islamic Hospital Ibnu Sina Magelang, then a market analysis was carried out so that it was able to produce problem formulations and in order to increase the trust of RSI Ibnu Sina Magelang.

According to data from the Magelang District Health Office through the Hospital Management Information System (SIM RS) as well as data from the Magelang District Central Bureau of Statistics, data on hospital visitors are as follows:

Table 1. Data on Community Users of Health Facilities Source BPS Magelang Regency

\begin{tabular}{ll}
\hline District Area & $\begin{array}{l}\text { Number of people } \\
\text { having health } \\
\text { complaints }\end{array}$ \\
\hline Salaman & 20.862 \\
\hline Borobudur & 17.619 \\
\hline Ngluwar & 9.152 \\
\hline Salam & 13.472 \\
\hline Srumbung & 13.731 \\
\hline Dukun & 13.181 \\
\hline Muntilan & 22.202 \\
\hline Mungkid & 20.888 \\
\hline Sawangan & 16.031 \\
\hline Candimulyo & 14.024 \\
\hline Mertoyudan & 30.723 \\
\hline Tempuran & 14.611 \\
\hline Kajoran & 16.849 \\
\hline Kaliangkrik & 16.734 \\
\hline
\end{tabular}




\begin{tabular}{ll} 
Bandongan & 17.092 \\
\hline Windusari & 14.439 \\
\hline Secang & 22.634 \\
\hline Tegalrejo & 14.972 \\
\hline Pakis & 15.154 \\
\hline Grabag & 26.092 \\
\hline Ngablak & 11.886 \\
\hline Kabupaten Magelang & $\mathbf{3 6 2 . 3 4 8}$
\end{tabular}

The data above shows that there are $27.98 \%$ of people using health facilities in 2019 , according to the survey, it is estimated that there are seven Districts in Magelang Regency, south side, including:

Table 2. Number of Communities Seven Districts Source BPS Magelang Regency

\begin{tabular}{lrc}
\hline District Area & $\begin{array}{l}\text { the number of } \\
\text { people in the } \\
\text { magelang district }\end{array}$ & $\begin{array}{l}\text { Number of people } \\
\text { having health } \\
\text { complaints }\end{array}$ \\
\hline Salaman & 74.561 & 20.862 \\
\hline Borobudur & 62.970 & 17.619 \\
\hline Mertoyudan & 109.803 & 30.723 \\
\hline Tempuran & 52.218 & 14.611 \\
\hline Kajoran & 60.217 & 16.849 \\
\hline Kaliangkrik & 59.808 & 17.092 \\
\hline Bandongan & 61.085 & $\mathbf{1 3 4 . 4 8 9}$ \\
\hline Kabupaten Magelang & $\mathbf{4 8 0 . 6 6 2}$ & \\
\hline
\end{tabular}

Marketing activities can be grouped by dividing the market into several groups based on variables such as age, gender, occupation, education level, generation and social class.

- Demographic segmentation analysis of old patients RSI Ibnu Sina Magelang divides respondents based on age, occupation and income.

Table 3. Age Segment Source of Survey Data for 2019

\begin{tabular}{llrrr}
\hline No. & Age & number of people & prosentase & \multicolumn{2}{c}{$\begin{array}{c}\text { number of } \\
\text { respondents }\end{array}$} \\
\hline 1 & $18-40$ years & 40 & $40 \%$ & 40 \\
\hline 2 & $41-55$ years & 30 & $20 \%$ & 30 \\
\hline 3 & $\geq 56$ years & 20 & $9 \%$ & 5 \\
\hline 4 & $10-17$ years & 10 & $10 \%$ & 10 \\
\hline Jumlah & $\mathbf{1 0 0}$ & $\mathbf{7 9 \%}$ & \\
\hline
\end{tabular}

The age group or productive age group tends to have a lot of requirements and higher expectations of the ability of health services, and tends to criticize the lack of services. 
Table 4. Profession Segment Source of Survey Data for 2019

\begin{tabular}{llrr}
\hline No. & Profession & $\begin{array}{l}\text { number of } \\
\text { respondents }\end{array}$ & prosentase \\
\hline 1 & Does not work & 3 & $3 \%$ \\
\hline 2 & Housewife & 36 & $38 \%$ \\
\hline 3 & entrepreneur & 10 & $11 \%$ \\
\hline 4 & Farmer & 22 & $23 \%$ \\
\hline 5 & Private employees & 2 & $2 \%$ \\
\hline 6 & Retired & 2 & $2 \%$ \\
\hline 7 & Government employees & 1 & $1 \%$ \\
\hline & & Jumlah & $\mathbf{8 1 \%}$ \\
\hline
\end{tabular}

Based on the work group of RSI Ibnu Sina Magelang, the dominating old patients are housewives, farmers and entrepreneurs in the nearest area.

- Psychographic Segmenting

In this segmentation, the market can be divided into different groups for analysis based on social class, lifestyle, personality, background, etc. Demographic information is very important, but it does not always provide sufficient information to divide consumers into segmented audiences, therefore it is necessary to segment according to psychological characteristics to better understand consumer characteristics.

Table 5. Income segment Source of Survey Data for 2019

\begin{tabular}{llrr}
\hline No. & Income & $\begin{array}{l}\text { number of } \\
\text { respondents }\end{array}$ & prosentase \\
\hline 1 & $300.000-1.000 .000$ & 5 & $6 \%$ \\
\hline 2 & $1.000 .000-2.000 .000$ & 34 & $38 \%$ \\
\hline 3 & $2.000 .000-3.500 .000$ & 22 & $24 \%$ \\
\hline 4 & $\leq 300.000$ & 2 & $2 \%$ \\
\hline 5 & $\geq 3.500 .000$ & 10 & $11 \%$ \\
\hline & & Jumlah & $\mathbf{8 1 \%}$
\end{tabular}

In the above analysis, it was found that some patients (62\%) had a monthly income of less than 3.5 million. This means that most of the RSI Ibnu Sina Magelang patients fall into the low to middle economic category. Judging from this socioeconomic group, respondents have a high purchasing power, because the level of income affects consumer demand and determines their purchasing power.

Table 6. Religius segment Source of Survey Data for 2019

\begin{tabular}{llll}
\hline No. Religius & $\begin{array}{l}\text { number of } \\
\text { respondents }\end{array}$ & prosentase \\
\hline
\end{tabular}




\begin{tabular}{llrr}
\hline 1 & Islam & 90 & $100 \%$ \\
\hline 2 & Kristen & 0 & $0 \%$ \\
\hline 3 & Katholik & 0 & $0 \%$ \\
\hline 4 & Hindu & 0 & $0 \%$ \\
\hline 5 & Budha & 0 & $0 \%$ \\
\hline & & Jumlah & $\mathbf{1 0 0 \%}$ \\
\hline
\end{tabular}

All respondents to the above internal survey data are Muslim, this Islamic hospital can be built to develop facilities and infrastructure related to Muslim worship, and the first Islamic hospital in the Magelang region will operate based on Islamic law. Because RSI Ibnu Sina is an Islamic Hospital, RSI Ibnu Sina provides comfortable and adequate worship facilities and can provide an Islamic spiritual path.

Table 7. Payment Segment Source of Survey Data for 2019

\begin{tabular}{llrr}
\hline No. & Income & $\begin{array}{l}\text { number of } \\
\text { respondents }\end{array}$ & prosentase \\
\hline 1 & Umum & 48 & $64 \%$ \\
\hline 2 & BPJS & 27 & $36 \%$ \\
\hline & & Jumlah & $\mathbf{1 0 0 \%}$ \\
\hline
\end{tabular}

From the data segmentation from internal data, the most payment methods are personal or general expenses as many as 48 respondents or $64 \%$ and by using BPJS by $36 \%$. Then the survey analysis was divided into two new patients and old patients. The results obtained from new respondents are $68 \%$ while respondents who are old patients are $32 \%$. In this matter, it means that RSI Ibnu Sina Magelang has the potential to get new patients, so that internal and external marketing can be carried out in order to increase the BOR of the hospital. Behavioral segmentation can also be done by looking at the selection of inpatient care classes by respondents at RSI Ibnu Sina Magelang.

Psychographic segmentation is carried out by looking at the selection of inpatient care classes desired by respondents at RSI Ibnu Sina Magelang.

Table 8. Segment Type Selection of Care Class Source of Survey Data for 2019

\begin{tabular}{llrr}
\hline No. & Care Class & $\begin{array}{l}\text { number of } \\
\text { respondents }\end{array}$ & prosentase \\
\hline 1 & Kelas I & 40 & $53 \%$ \\
\hline 2 & Kelas 3 & 16 & $21 \%$ \\
\hline 3 & Kelas 2 & 14 & $19 \%$ \\
\hline 4 & VIP & 5 & $7 \%$ \\
\hline & & Jumlah & $\mathbf{1 0 0 \%}$ \\
\hline
\end{tabular}


A total of $53 \%$ of the above data chose to be treated in class 1 . In terms of segmentation, the selection of classes according to the patient's monthly income, most of them earn less than 3.5 million per month. In selecting the class of patient care that uses health facilities, it shows their social class in society.

Based on the results of internal survey data and analysis, it can be seen that the psychographic segmentation for inpatient health facilities at RSI Ibnu Sina Magelang belongs to the middle to lower class and in the community income survey data, most of which are $<3.5$ million, mostly 18-40 years old with female gender and do not work where their daily activities as a housewife. This market segmentation can be grouped by hospitals as potential targets for the development of RSI Ibnu Sina Magelang using internal and external marketing.

\subsection{Research on five competitive forces}

IFE Matrix and EFE Matrix are used to determine the response of a business entity to external and internal factors. Determination of weight and rating for each strength, weakness, opportunity, and threat was carried out in this study with the owner of RSI Ibnu Sina Magelang through interviews and observations of competitors. Brainstorming is very necessary because players in the health service business understand much more about the factors that affect their business.

According to David (2011), the Internal Factor Evaluation (IFE) Matrix is used to analyze and evaluate the main strengths and weaknesses that occur in the functional areas of the business and also serve as a basis for identifying and evaluating the relationships between these areas. By using the IFE Matrix, it can be seen the factors of major strength and major weakness that are the response of a business entity.

Major strength possessed by the Islamic Hospital Ibnu Sina Magelang is Brand Awareness which has become the closest hospital in the location with a weight of 0.2 and a rating of 4 . The level of public trust is also a major factor in the health service business. At the maximum level of service, of course, will be customer or patient satisfaction.

The major weakness of Ibnu Sina Magelang Islamic Hospital is that the hospital has not operated until now, which has a weight of 0.1 and a rating of 4 , financial factors are also a fundamental factor so that the hospital can be reopened immediately. While the weakness factors of the Islamic Hospital Ibnu Sina Magelang which has the smallest weight are the use and maintenance of medical devices that are not optimal with a weight of 0.03 and a rating of 2 . In the health service business the most important thing is health services and facilities.

Through this analysis, it can be described the position of RSI Ibnu Sina Magelang in the competition for current market share through the following SWOT analysis diagram:

Point $\mathrm{X}=$ Opportunity - Threat

Total Opportunity rating weight $\quad=2,40$ 
Total Threat rating weight

$$
\begin{aligned}
& =0,95- \\
& =1,45
\end{aligned}
$$

Titik $\mathrm{Y}=$ Strength - Weakness

Total Strength rating weight

$$
=2,50
$$

Total Weakness rating weight

$$
\begin{aligned}
& =0,80- \\
& =1,70
\end{aligned}
$$

Picture 1 Diagram SWOT

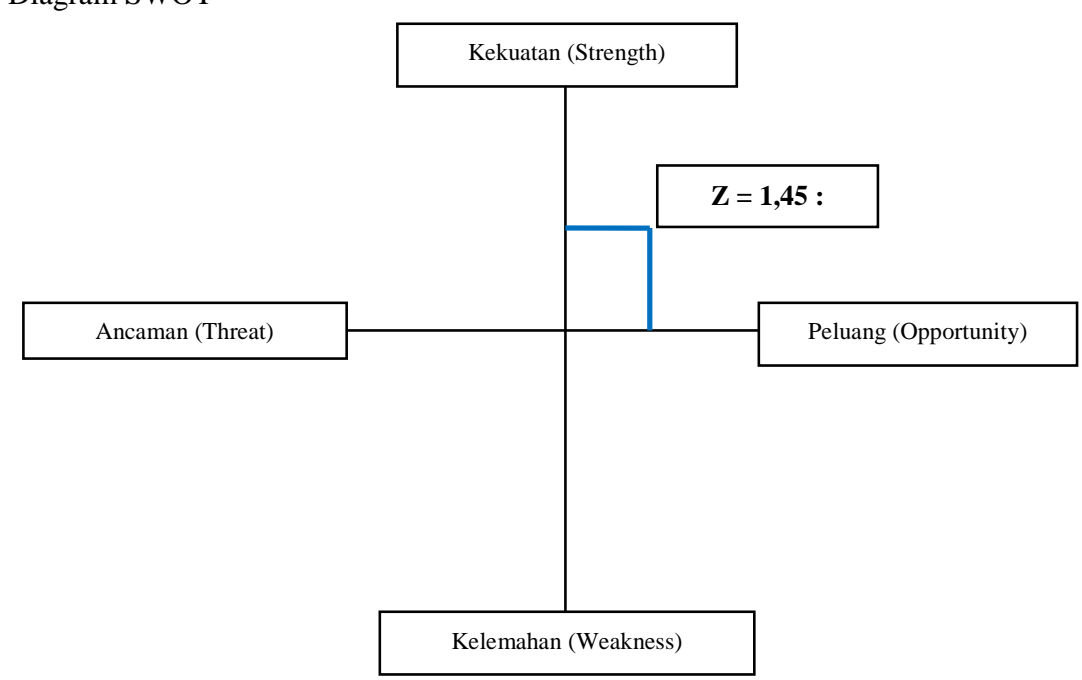

Picture Explanation:

$\mathrm{Z}=$ means that RSI Ibnu Sina Magelang is in quadrant I where RSI Ibnu Sina Magelang can use the SO (Strength - Opportunity) strategy, namely RSI Ibnu Sina Magelang will use its superior sector strategy to take advantage of the opportunities that exist in serving customers.

Table 8. Matriks SWOT RSI Ibnu Sina Magelang

\begin{tabular}{lll}
\hline IFE & \multicolumn{1}{c}{ KEKUATAN (Strength) } & \multicolumn{1}{c}{ KELEMAHAN (Weakness) } \\
\hline $\begin{array}{l}\text { Familiar brand awareness } \\
\text { Level of community trust }\end{array}$ & The hospital has yet to operate \\
& $\begin{array}{l}\text { Availability of standard service } \\
\text { procedures and accredited work } \\
\text { procedures. }\end{array}$ & $\begin{array}{l}\text { The limitations of the existing } \\
\text { specialist doctors mean that services } \\
\text { are not maximized }\end{array}$ \\
& $\begin{array}{l}\text { Extensive land ownership } \\
\text { The availability of materials and tools } \\
\text { is sometimes not on time }\end{array}$ \\
& $\begin{array}{l}\text { Development of educational } \\
\text { facilities and infrastructure }\end{array}$ & $\begin{array}{l}\text { The use and maintenance of medical } \\
\text { equipment is not optimal }\end{array}$ \\
\hline
\end{tabular}




\section{Peluang}

(Opportunity)

Strategic location.

Optimistic with old patient visit data

The public is more familiar with the quality of RSI Ibnu Sina Magelang

Already accredited nationally, and in the process of license extension

Public awareness of health is increasing

Ancaman

(Threat)

Financial

Unstable

BPJS Budget

Deficit Issues

The existence of the latest standard of accreditation completeness to meet the new licensing requirements

The availability of tools and medicines is very

\section{Strategi SO}

The management of the licensing extension of the Ibnu Sina Magelang Islamic Hospital will be implemented soon (S1, O1).

Continue to provide the best service in serving public health (S4, O3).

RSI Ibnu Sina Magelang continues to maintain and improve customer loyalty and service quality in the health sector (S5, O4).

\section{Strategi WO}

Attracting investors to invest in the health service business, because RSI Ibnu Sina and the public are enthusiastic about the reopening of the hospital (W1, O3)

Carry out increased commitment and productivity to provide quality services and oriented to customer needs (W3, O3).

Conduct training to improve employee skills and discipline at work (W3, O4).

$\begin{array}{cc}\text { Strategi ST } & \text { Strategi WT }\end{array}$

Attract investors to invest in the health service business, provide matching funds so that financial management can be conditioned (S1, T1,2)

Conduct education and training on service quality and service standardization in accordance with regulations (S2, T2).

Carry out the construction of adequate facilities in accordance with the planned stages at the location of RSI Ibnu Sina Magelang (S5, T3).

Negotiations make contracts with long-term drug suppliers, (S3, T3)
Conduct training for medical and non-medical personnel in order to support health services, as well as in collaboration with health universities (W3, T4).

Negotiation making contracts with long-term drug suppliers (W4, T3)

Conduct training for medical and non-medical personnel on equipment use and maintenance (W5, T3) 
dependent on the

supplier

There are

restrictions for

doctors who

practice $\quad 3$

workplaces at

once

Issue Opening

opportunities for

foreign human

resources to be

more professional

in other hospitals

\subsection{Research Using Financial Analysis}

Magelang regency economy which is measured based on the amount of gross regional domestic product (PDRB) at the current price in 2019 reaches Rp. 32.490 trillion, while at constant 2010 prices it reached Rp. 23.25 trillion (source website BPS Magelang Regency).

Capital structure or capital structure refers to the amount of debt or equity that the organization uses to finance its operations and finance its assets. The capital structure of a hospital business is usually expressed as the ratio of debt to equity or ratio of debt to equity.

Capital structure is a very important point in business structure. The quality of the capital structure will directly affect the company's financial status, especially if there is sufficient debt to support the company's performance.

Each company uses a capital budget that is used to analyze the fixed asset investment plan that will be implemented. The results of the analysis are used as the basis for determining the amount of funds that the company spends for investment.

In the analysis of this research, capital budgeting has several analytical calculations, namely:

\section{Average Rate Of Return calculation}

The calculation of the average rate of return is based on the amount of net profit after tax (EAT) that appears in the income statement.

$$
\begin{gathered}
\mathrm{ARR}=\frac{\text { average earning after tax }}{\text { Average investment }} \times 100 \% \\
\text { Average investment }=\frac{\text { investment }}{2} \\
\mathrm{ARR}=\frac{\text { (Rp. } 177.835 .235 .396 / 2)}{\text { Rp. } 133.200 .000 .000} \times 100 \%
\end{gathered}
$$




\section{Average Rate Of Return $=\quad 66.75 \%$}

Payback Period

Payback Period calculation for a project that has the same cash inflow pattern from year to year can be done as follows:

$$
\mathrm{PP}=\frac{\text { initial investment }}{\text { cash inflow }} \times 1 \text { Tahun }
$$

Payback Period calculation can be formulated as follows:

$$
\text { Payback Period }=\quad \mathrm{t}+\frac{\mathrm{b}-\mathrm{c}}{\text { cash inflow }} \times 1 \text { Tahun }
$$

\section{Payback Period Calculation Projection}

\begin{tabular}{cccccc}
\hline & & Initial Investment Value & Rp & & 133.200.000.000,00 \\
\hline $\begin{array}{c}\text { Current } \\
\text { year }\end{array}$ & & Cash flow & & Cumulative Cash Flow & $\begin{array}{c}\text { Year } \\
\text { Completed }\end{array}$ \\
\hline \hline Year 1 & $\mathrm{Rp}$ & $19.871 .337 .620,66$ & $\mathrm{Rp}$ & $19.871 .337 .620,66$ & 5,879 \\
\hline Year 2 & $\mathrm{Rp}$ & $23.229 .593 .678,56$ & $\mathrm{Rp}$ & $43.100 .931 .299,22$ & 5,318 \\
\hline Year 3 & $\mathrm{Rp}$ & $27.155 .395 .010,23$ & $\mathrm{Rp}$ & $70.256 .326 .309,45$ & 4,983 \\
\hline Year 4 & $\mathrm{Rp}$ & $31.744 .656 .766,96$ & $\mathrm{Rp}$ & $102.000 .983 .076,41$ & 4,841 \\
\hline Year 5 & $\mathrm{Rp}$ & $37.109 .503 .760,58$ & $\mathrm{Rp}$ & $139.110 .486 .836,99$ & 4,864 \\
\hline Year 6 & $\mathrm{Rp}$ & $43.381 .009 .896,12$ & $\mathrm{Rp}$ & $182.491 .496 .733,11$ & 5,028 \\
\hline Year 7 & $\mathrm{Rp}$ & $50.712 .400 .568,56$ & $\mathrm{Rp}$ & $233.203 .897 .301,67$ & 6,571 \\
\hline \hline
\end{tabular}

\section{Investments can be completed in year 6}

Net Present Value (NPV)

Net Present Value is a technique that takes into account the time / money value that is most widely used. The calculation of the net present value is carried out as follows:

$$
N P V=\text { present } \text { cash inflow }- \text { present value investment }
$$

\begin{tabular}{lcccc}
\hline & \multicolumn{4}{l}{ Calculation Projection Net Present Value (NVP) } \\
\hline & Initial Investment Value & Rp & $\mathbf{1 3 3 . 2 0 0 . 0 0 0 . 0 0 0 , 0 0}$ \\
\hline \multirow{2}{*}{ Current year } & & Cash flow & Disconto 10\% & Value of Cash Flow \\
& & & & \\
\hline \hline Year 1 & Rp & $19.871 .337 .620,66$ & 0,909 & $18.064 .852 .382,422$ \\
\hline
\end{tabular}




\begin{tabular}{|c|c|c|c|c|}
\hline Year 2 & $\mathrm{Rp}$ & 23.229.593.678,56 & 0,826 & 19.198.011.304,592 \\
\hline Year 3 & $\mathrm{Rp}$ & $27.155 .395 .010,23$ & 0,751 & $20.402 .250 .195,516$ \\
\hline Year 4 & $\mathrm{Rp}$ & $31.744 .656 .766,96$ & 0,683 & $21.682 .027 .707,780$ \\
\hline Year 5 & $\mathrm{Rp}$ & $37.109 .503 .760,58$ & 0,621 & $23.042 .082 .173,087$ \\
\hline Year 6 & $\mathrm{Rp}$ & $43.381 .009 .896,12$ & 0,564 & $24.487 .449 .145,762$ \\
\hline Year 7 & $\mathrm{Rp}$ & $50.712 .400 .568,56$ & 0,513 & $26.023 .480 .046,724$ \\
\hline \multicolumn{4}{|c|}{ Total Cash Flow } & $152.900 .152 .955,882$ \\
\hline \multicolumn{4}{|c|}{ Initial Investment Value } & 133.200.000.000,000 \\
\hline \multicolumn{4}{|c|}{ NET PRESENT VALUE (NVP) } & $19.700 .152 .955,882$ \\
\hline
\end{tabular}

Benefit Cost Ratio (B / C Ratio)

Benefit Cost Ratio or also known as the profitability index. In this approach it is almost the same as the NPV technique, except that the B / C Ratio measures the present value for each rupiah invested. The calculation of B / C Ratio is carried out as follows:

$$
\mathrm{B} / \mathrm{C} \text { Ratio }=\frac{\text { Present value cash inflow }}{\begin{array}{c}
\text { Present value initial } \\
\text { investment }
\end{array}}
$$

PROYEKSI PERHITUNGAN B/C

\begin{tabular}{|c|c|c|c|c|c|}
\hline Year & Cost & Benefit & Netbenefit & $\begin{array}{l}\text { Disconto } \\
10 \%\end{array}$ & PV \\
\hline 0 & 77.000 .000 .000 & - & - 77.000 .000 .000 & 0,909 & - $\quad 70.000 .000 .000$ \\
\hline 1 & 46.481 .507 .379 & 66.352 .845 .000 & - 57.128 .662 .379 & 0,826 & - $\quad 47.213 .770 .561$ \\
\hline 2 & 54.336 .882 .126 & 77.566.475.805 & - 33.899 .068 .701 & 0,751 & - $\quad 25.468 .872 .052$ \\
\hline 3 & 63.519 .815 .206 & 90.675 .210 .216 & 6.743 .673 .691 & 0,683 & 4.606.019.869 \\
\hline 4 & 74.254.663.976 & 105.999 .320 .743 & 25.000 .983 .076 & 0,621 & 15.523 .643 .490 \\
\hline 5 & 86.803 .702 .187 & 123.913 .205 .948 & 62.110 .486 .837 & 0,564 & 35.059 .750 .602 \\
\hline 6 & 101.473.527.857 & 144.854 .537 .753 & 105.491 .496 .733 & 0,513 & 54.133 .817 .953 \\
\hline 7 & 118.622 .554 .065 & 169.334 .954 .634 & 156.203 .897 .302 & 0,467 & 72.870 .270 .909 \\
\hline
\end{tabular}

$\mathrm{B} / \mathrm{C}$ Ratio $=\frac{\text { Rp. } 177 \cdot 587.482 .953}{\text { Rp. } 147 \cdot 288 \cdot 662.482}=1,2057 \%$

Since the $\mathrm{B} / \mathrm{C}$ value is $\geqslant 1$, the purchase of the new equipment is considered profitable. 
Internal Rate of Return (IRR)

Internal Rate of Return is the discount rate that will cause the NPV to be zero, because the present value of cash inflow at the discount rate will be the same as the initial investment. The calculation of IRR must be done by "trial and error" (trial and error) until a discount rate is obtained which will cause the NPV to be zero. In calculating the IRR, an interpolation method is used to determine the true IRR with the following formula:

$$
\mathrm{IRR}=\mathrm{rk}+\frac{\mathrm{NPV} r \mathrm{rk}}{\mathrm{TPV} r \mathrm{r}-\mathrm{TPV} \mathrm{rb}} \times(\mathrm{rb}-\mathrm{rk})
$$

At a discount rate of $10 \%$ and a maximum of $15 \%$, respectively, a positive and negative NPV is obtained, then the trial and error process is continued with interpolation to determine the true IRR value.

\begin{tabular}{|c|c|c|c|c|c|c|}
\hline \multicolumn{7}{|c|}{ PROYEKSI PERHITUNGAN INTERNAL RATE RETURN } \\
\hline \multicolumn{7}{|c|}{ Diskonto 1 sebesar $10 \%$} \\
\hline Tahun & Arus Kas & Diskonto & Nilai & & & PV \\
\hline 1 & Rp19.871.337.620,66 & $10 \%$ & 0,9090909 & $\mathrm{Rp}$ & 18.0 & $4.852 .382,42$ \\
\hline 2 & Rp23.229.593.678,56 & $10 \%$ & 0,8264463 & $\mathrm{Rp}$ & 19.1 & $8.011 .304,59$ \\
\hline 3 & Rp27.155.395.010,23 & $10 \%$ & 0,7513148 & $\mathrm{Rp}$ & 20.4 & $2.250 .195,52$ \\
\hline 4 & Rp31.744.656.766,96 & $10 \%$ & 0,6830135 & $\mathrm{Rp}$ & 21.6 & $2.027 .707,78$ \\
\hline 5 & Rp37.109.503.760,58 & $10 \%$ & 0,6209213 & $\mathrm{Rp}$ & 23.0 & $2.082 .173,09$ \\
\hline 6 & Rp43.381.009.896,12 & $10 \%$ & 0,5644739 & $\mathrm{Rp}$ & 24.4 & $7.449 .145,76$ \\
\hline 7 & Rp50.712.400.568,56 & $10 \%$ & 0,5131581 & $\mathrm{Rp}$ & 26.0 & $3.480 .046,72$ \\
\hline \multicolumn{5}{|c|}{ Jumlah Total } & $\mathbf{R p}$ & 152.900.152.955,88 \\
\hline \multicolumn{5}{|c|}{ Modal Inti / Awal } & $-\mathbf{R p}$ & 133.200.000.000,00 \\
\hline \multicolumn{5}{|c|}{ Selisih (Jumlah Total - Modal Inti) } & $\mathbf{R p}$ & 19.700.152.955,88 \\
\hline
\end{tabular}

\section{Diskonto 2 sebesar $15 \%$}

\begin{tabular}{|c|c|c|c|c|c|}
\hline Tahun & Arus Kas & Diskonto & Nilai & & PV \\
\hline 1 & Rp19.871.337.620,66 & $15 \%$ & 0,8695652 & $\mathrm{Rp}$ & 17.279.424.017,97 \\
\hline 2 & Rp23.229.593.678,56 & $15 \%$ & 0,7561437 & $\mathrm{Rp}$ & $17.564 .910 .153,92$ \\
\hline 3 & Rp27.155.395.010,23 & $15 \%$ & 0,6575162 & $\mathrm{Rp}$ & $17.855 .113 .017,33$ \\
\hline 4 & Rp31.744.656.766,96 & $15 \%$ & 0,5717532 & $\mathrm{Rp}$ & $18.150 .110 .536,75$ \\
\hline 5 & Rp37.109.503.760,58 & $15 \%$ & 0,4971767 & $\mathrm{Rp}$ & $18.449 .981 .928,22$ \\
\hline 6 & Rp43.381.009.896,12 & $15 \%$ & 0,4323276 & $\mathrm{Rp}$ & $18.754 .807 .716,60$ \\
\hline 7 & Rp50.712.400.568,56 & $15 \%$ & 0,375937 & $\mathrm{Rp}$ & 19.064.669.757,14 \\
\hline \multicolumn{4}{|c|}{ Jumlah Total } & $\mathrm{Rp}$ & 127.119.017.127,93 \\
\hline
\end{tabular}




\begin{tabular}{rrrr}
\hline Modal Inti / Awal & $-\mathrm{Rp}$ & $133.200 .000 .000,00$ \\
\hline Selisih (Jumlah Total - Modal Inti) & $-\mathrm{Rp}$ & $6.080 .982 .872,07$ \\
\hline
\end{tabular}

$$
\operatorname{IRR}=10+\frac{19.700 .152 .955 \times(15 \%-10 \%)}{(19.700 .152 .955-(-6.080 .982 .872))}=13,82 \%
$$

\section{CONCLUSION}

The results of the evaluation of capital budgeting use the average rate of return (ARR), payback period (PP), net present value (NPV), benefit-cost ratio (B / C ratio) method to evaluate the investment plan of the Islamic Hospital Ibnu Sina Magelang. The feasibility of the business is declared feasible to be implemented, because it meets the investment evaluation criteria, hence the internal rate of return (IRR) investment is feasible for the development and development of health services. Based on the results of the calculation and evaluation of the capital budget, it can be concluded that the investment plan for the development and development of health services at the Islamic Hospital Ibnu Sina Magelang is very feasible.

\section{Acknowledgements}

These and the Reference headings are in bold but have no numbers. Text below continues as normal.

\section{References}

Cheng, D. S. Y. (2013). "Analyze the Hotel Industry in Porter Five Competitive Forces." The Journal of Global Business Management 9(3): 52-57

Martin (2014). "Bargaining Power Of Buyers: Porter's Five Forces Model." From https://www.cleverism.com/bargaining-power-ofbuyers-porters-fiveforces-model/.

Menkes (2014). Permenkes no.56 tentang Klasifikasi dan Perizinan Rumah Sakit. K. Kesehatan.

Pringle, J. dan J. Huisman (2011). "Understanding Universities in Ontario, Canada: An Industry Analysis Using Porter's Five Forces Framework." Canadian Journal of Higher Education 41(3): 36 - 58

Wibisono, M. S. dan M. Hamsal (2013). "Business Strategy Development and Business Model RS .Bakti Timah ( RSBT ) Groups Pangkal Pinang under Bakti Timah Foundation ( YBT ) become PT. RS Bakti Timah As An Existance Of Diversification Effort From PT.Timah (PERSERO) TBK." The Indonesian Journal of Business Administration 2(16): 2010-2019.

Wilkinson, J. (2013). "Porter's Five Forces of Competition." Retrieved 12 Desember, 2017, from https://strategiccfo.com/portersfive- forces-of-competition/.

Kotler, Philip. 2002. Prinsip-Prinsip Pemasaran terjemahan, Edisi 9. Jakarta: Erlangga. 2007. Marketing Management terjemahan. Jakarta: Erlangga. 2008. Manajemen Pemasaran terjemahan, Edisi 12. Jakarta: Erlangga

Sugiyono. 2008. Metodologi Penelitian Bisnis. Bandung: Alphabeta. 2011. Metode Penelitian Kualitatif dan RnD. Bandung: Alphabeta

Porter, M. E., 1980. Competitive Strategy-Techniques for Analyzing Industries and Competitors. New York, The Free Press. 


\section{Corresponding author}

Mochamad Yusuf Kurniawan can be contacted at : toyie_fuchi@yahoo.com 